\title{
Consciência fonológica e habilidades de escrita em crianças com síndrome de Down***
}

\author{
Phonological awareness and writing skills in children with Down \\ syndrome
}

\begin{abstract}
Bárbara de Lavra-Pinto*
Regina Ritter Lamprecht**
\end{abstract}

*Fonoaudióloga. Mestre em Letras na Área de Linguística pela Pontifícia Universidade Católica do Rio Grande do Sul (PUCRS). Fonoaudióloga da Universidade Federal do Rio Grande do Sul (UFRGS). Endereço para correspondência: Av. Venâncio Aires, 70 / 401 - Porto Alegre RS - CEP 90040-190 (barbaradlp@ig.com.br).

**Linguista. Doutora em Letras na Área de Linguística pela PUCRS. Professora do Programa de PósGraduação em Letras da PUCRS. Coordenadora do Centro de Estudos sobre Aquisição e Aprendizagem da Linguagem (CEAAL).

***Trabalho Realizado no CEAAL, Vinculada ao Programa de Pós-Graduação em Letras na Área de Linguística, da PUCRS.

Artigo Original de Pesquisa

Artigo Submetido a Avaliação por Pares

Conflito de Interesse: não

Recebido em 05.07.2009.

Revisado em 12.04.2010.

Aceito para Publicação em 01.09.2010.

\begin{abstract}
Background: Down syndrome, phonological awareness, writing and working memory. Aim: to evaluate the phonological awareness of Brazilian children with Down syndrome; to analyze the relationship between the writing hypothesis and the phonological awareness scores of the participants; to compare the performance of children with Down syndrome to that of children with typical development according to the Phonological Awareness: Tool for sequential evaluation (PHONATSE), using the writing hypothesis as a matching criteria; to verify the correlation between the phonological awareness measurements and the phonological working memory. Method: a group of eleven children aged between 7 and 14 years (average: 9y10m) was selected for the study. Phonological awareness was evaluated using the PHONATSE. The phonological working memory was evaluated through an instrument developed by the researcher. Results: all subjects presented measurable levels of phonological awareness through the PHONATSE. The phonological awareness scores and the writing hypothesis presented a significant positive association. The performance of children with Down syndrome was significantly lower than children with typical development who presented the same writing hypothesis. Measurements of phonological awareness and phonological working memory presented significant positive correlations. Conclusion: the phonological awareness of Brazilian children with Down syndrome can be evaluated through the PHONATSE. Syllable awareness improves with literacy, whereas phonemic awareness seems to result from written language learning. The phonological working memory influences the performance of children with Down syndrome in phonological awareness tasks.
\end{abstract}

Key Words: Down Syndrome; Language Arts; Handwriting; Memory.

\section{Resumo}

Tema: síndrome de Down, consciência fonológica, escrita e memória de trabalho. Objetivos: avaliar a consciência fonológica de crianças brasileiras com síndrome de Down. Analisar a relação existente entre as hipóteses de escrita dos participantes e os escores de consciência fonológica. Comparar o desempenho de crianças com síndrome de Down aos resultados esperados para crianças com desenvolvimento típico de acordo com a Conciência Fonológica. Instrumento de Avaliação Sequencial (CONFIAS), utilizando as hipóteses de escrita como critério de emparelhamento. Verificar a correlação entre medidas de consciência fonológica e memória de trabalho fonológica. Método: onze crianças com idades cronológicas entre 7 e 14 anos (média: 9a10m) constituíram a amostra. A consciência fonológica foi avaliada utilizando-se o CONFIAS. A memória de trabalho fonológica foi avaliada através de um instrumento elaborado pela pesquisadora. Resultados: os sujeitos avaliados apresentaram níveis mensuráveis de consciência fonológica por meio da aplicação do CONFIAS. Os escores de consciência fonológica e as hipóteses de escrita apresentaram associação positiva significativa. O desempenho das crianças com síndrome de Down foi significativamente inferior ao de crianças com desenvolvimento típico e mesma hipótese de escrita. As medidas de consciência fonológica e de memória de trabalho fonológica apresentaram correlações positivas significativas. Conclusão: a consciência fonológica de crianças brasileiras com síndrome de Down pode ser avaliada utilizando-se o CONFIAS. A consciência silábica aprimora-se com a alfabetização, já a consciência fonêmica parece surgir como resultado do aprendizado da língua escrita. A memória de trabalho fonológica influencia o desempenho de crianças com a síndrome em tarefas de consciência fonológica.

Palavras-Chave: Síndrome de Down; Estudos de Linguagem; Escrita Manual; Memória.

Referenciar este material como:

1 Lavra-Pinto B, Lamprecht RR. Phonological awareness and writing skills in children with Down syndrome (original title: Consciência fonológica e habilidades $\sum 3$ de escrita em crianças com síndrome de Down). Pró-Fono Revista de Atualização Científica. 2010 jul-set;22(3):287-92. 


\section{Introduction}

This study investigates the ability of phonological reflection of children with Down syndrome speakers of Brazilian Portuguese. These skills, along with the ability of syllable, rhyme and phoneme operation, constitute phonological awareness1.

Studies on phonological awareness of children with Down syndrome were first reported in the 1990s with publications of Cossu and Marshall 2 and Cossu et al3. These authors argued that individuals with that syndrome could learn to read without presenting phonological awareness skills. This conclusion spurred researchers from different countries to investigate measurable levels of phonological awareness in individuals with Down syndrome and its relationship with their reading skills 4-19.

The first purpose of the current study was to determine whether children with Down syndrome speakers Brazilian Portuguese have measurable levels phonological awareness through the application of CONFIAS1. The second purpose of the study was to analyze the relationship between different writing hypothesis20 and phonological awareness of the participants. The third purpose was to compare the performance of children with Down syndrome in the phonological awareness assessment to the performance expected for children with typical development using the writing hypothesis as a group matching criterion. The fourth purpose was to investigate the correlation between phonological awareness and working memory of the participants of the study.

\section{Method}

This study resulted from an observational and transversal research approved by the Research Ethics Committee of PUCRS (08/04114). All parents or guardians of the participants signed a consent form. The Institutional Informed Consent Form was as well signed by officials from the participating institutions. The sampling procedure was performed according to accessibility. The established inclusion criteria were: monolingual speakers of Brazilian Portuguese, literate or under literacy process, who were enrolled in special classes at regular schools or under inclusion process in elementary schools.

Exclusion criteria were: sensorineural or mixed hearing loss and/or uncorrected visual disorder and associated comorbidities - neurological impairments caused by the Down syndrome, autism or psychosis diagnosis, and emotional alterations diagnosed by psychologist or psychiatrist that would impair the performance of child.
The sample consisted of 11 children with Down syndrome, six boys and five girls, with chronological ages between seven and 14 years (mean age 9:10 years, SD 2:3 years). In Porto Alegre (RS), five children were tested at the Center Lydia Coriat and four at the State School of Elementary Education Visconde de Pelotas. In Novo Hamburgo (RS), two children were tested at their homes.

Ten children had simple trisomy of chromosome 21 and only one was a carrier of the mosaicism type. Data related to chronological age, gender, type of Down syndrome, clinical characteristics related to hearing and vision, school history and comorbidities were collected through a questionnaire prepared by the researcher and applied to parents and children.

All participants were, prior to data collection, referred for consultation with Otolaryngologists and for Audiologists for conditioned audiometry and impedance measures. Only two children presented alterations (flat tympanometric curve type B21). These participants were not excluded from the sample due to the possibility that, at first, this alteration would not affect the pure tone thresholds.

The phonological awareness: sequential assessment tool (Consciência fonológica: instrumento de avaliação sequencial-CONFIAS1) was used for the assessment of phonological awareness. The use of this instrument enables the investigation of metalinguistic skills considering the writing hypothesis 20. The 16 tasks of CONFIAS are divided at the levels of syllable and phoneme. The levels are presented in a gradation of increasing difficulty and consider the development of phonological awareness skills in children with typical development. The section of CONFIAS referring to the syllable level was applied during the first meeting with each child. The phonological awareness section was applied during a second meeting.

Modifications in the scoring criteria of CONFIAS were made for the application of the test in children with Down syndrome. During the pilot data collection, it was observed that the first response of children was most often inadequate because of inattention, inadequate comprehension of the order or by working memory interference. When the order was repeated, the responses were more reliable. A second chance to respond was then allowed and was considered for scoring. When the participant needed more than two opportunities to respond, the response was disregarded.

When the child did not score on two complete tasks, the evaluation was stopped. The CONFIAS provides tables with expected results for typically developing children according to their writing hypothesis. 
The collection of writing data of participants was performed using a children's story book. Children were requested to write, besides their name, three words (cat, castle and skeleton) and a sentence (The ghost opened the door). These data were analyzed according to the design process of appropriation of the written language (Smith \& Teberosky20) which allows the classification of children into general levels namely: pre-syllabic writing hypothesis, syllabic hypothesis, syllabicalphabetic hypothesis, and alphabetic hypothesis.

The instrument used for the assessment of phonological memory was elaborated by the researcher (Appendix) based on studies that aimed to evaluate the word span in children with Down syndrome 22-23. The instrument developed consists of 14 sequences of disyllabic and trisyllabic words, with a total of 46 words. The sequences were verbally presented and the child was asked to repeat the memorized words. The total score was the number of words correctly repeated during the evaluation. The number of correctly repeated sequences also provided a measure of phonological working memory.

The SPSS software version 13.0 was used for data analysis. Quantitative data were expressed as mean and standard deviation (symmetric distribution) or median and range (asymmetric distribution). The Student t test for independent samples was used on the comparison of phonological awareness scores among the writing hypotheses through. The Student $t$ test for one sample was used to compare the performance of children with Down syndrome to the performance of children with typical development according to their writing hypothesis. Spearman's correlation was used to analyze the association between the continuous variables (phonological awareness and working memory). The adopted significance level was of $5 \%(p ? 0.05)$.

\section{Results}

Table 1 displays the scores obtained by the participants in the phonological awareness assessment - CONFIAS1. The results revealed that children with Down syndrome from the current study presented measurable levels of phonological awareness using the CONFIAS. The participants reached higher scores in the syllable level (SL) when compared to the phonemic level (PL) tasks. The rhyme production, transposition and phonemic segmentation tasks were the most difficulty ones for the sample studied. For the analysis of the second aim of the study, the children were divided into groups according to their writing hypothesis 20. Six children (54.5\%) composed the group of participants with pre-syllabic writing hypothesis and four (36.4\%) composed the group of children with alphabetic writing hypothesis. Only one child (9.1\%) presented syllabic writing hypothesis. This child was excluded from the analysis that considered the participants according to writing hypothesis. The participants with alphabetic writing hypothesis scored significantly higher than the presyllabic children ( $p<0.001$ in SL, FL and in the total assessment). These results show that the more advanced the level of writing, the better the performance in the assessment of phonological awareness. Figure 1 shows the between-groups comparison according to the interval with 95\% confidence.

The groups of children with Down syndrome and typical development with pre-syllabic and alphabetic writing hypothesis presented significant differences in SL, FL and total phonological awareness score (Table 2). Although children with Down syndrome presented measurable values of phonological awareness, their average performance was significantly below that of typically developing children, even when the writing hypothesis - which is a cognition measure - was used as a matching criterion.

Positive correlation was found between the total phonological awareness score and phonological memory of participants of the sample ( $\mathrm{rs}=0.823$, $\mathrm{p}$ $<0.001$ ). Total phonological awareness score was also positively correlated with SL (rs $=0.831, \mathrm{p}=$ 0.002 ) and FL scores ( $r s=0.685, p=0.020)$. The maximum number of complete sequences correctly repeated showed significant positive correlation with the two levels of phonological awareness (rs $=0.895, \mathrm{p}<0.001$ for SL, rs $=0.794, \mathrm{p}<0.001$ for FL) and with the total score ( $r s=0.889, \mathrm{p}<0.001$ ). 
TABLE 1. Phonological awareness performance of the participants - CONFIAS .

\begin{tabular}{l|c|c|c|c|c|c}
\hline \multicolumn{1}{c|}{ Scores } & Possible & Mean & SD & Median & Minimum & Maximum \\
\hline SL- total & Variation* & & & & \\
S1- synthesis & $0-40$ & 18,8 & 9,76 & 16,0 & 6,00 & 34,0 \\
S2- segmentation & $0-4$ & 3,09 & 1,47 & 4,00 & 0,00 & 4,00 \\
S3- initial syllable identification & $0-4$ & 3,36 & 1,03 & 4,00 & 1,00 & 4,00 \\
S4- rhyme identification & $0-4$ & 1,82 & 1,47 & 2,00 & 0,00 & 4,00 \\
S5- Word production with syllable provided & $0-4$ & 2,45 & 1,37 & 3,00 & 0,00 & 4,00 \\
S6- medial syllable identification & $0-4$ & 2,82 & 1,40 & 3,00 & 0,00 & 4,00 \\
S7- rhyme production & $0-4$ & 1,55 & 1,81 & 0,00 & 0,00 & 4,00 \\
S8- exclusion & $0-4$ & 0,27 & 0,47 & 0,00 & 0,00 & 1,00 \\
S9- transposition & $0-8$ & 2,00 & 2,28 & 1,00 & 0,00 & 6,00 \\
PL- total & $0-4$ & 1,45 & 1,57 & 1,00 & 0,00 & 4,00 \\
F1- production of syllable beginning with the sound provided & $0-30$ & 7,91 & 6,02 & 5,00 & 1,00 & 18,0 \\
F2- initial phoneme identification & $0-4$ & 2,36 & 1,12 & 2,00 & 1,00 & 4,00 \\
F3- final phoneme identification & $0-4$ & 1,55 & 1,51 & 1,00 & 0,00 & 4,00 \\
F4- exclusion & $0-6$ & 1,36 & 1,63 & 1,00 & 0,00 & 4,00 \\
F5- synthesis & $0-4$ & 1,27 & 1,35 & 1,00 & 0,00 \\
F6- segmentation & $0-4$ & 0,18 & 1,17 & 1,00 & 0,00 & 4,00 \\
F7- transposition & $0-4$ & 0,00 & 0,60 & 0,00 & 0,00 & 3,00 \\
Total score & $0-70$ & 26,7 & 15,6 & 0,00 & 0,00 & 2,00 \\
& & & & & 0,00 \\
\end{tabular}

Note: SL = syllabic level; PL = phonemic level; SD = standard deviation; *possible variation of scores as established by the instrument.

FIGURE 1. Comparison between pre-syllabic and alphabetic children according to performance on phonological awareness assessment.

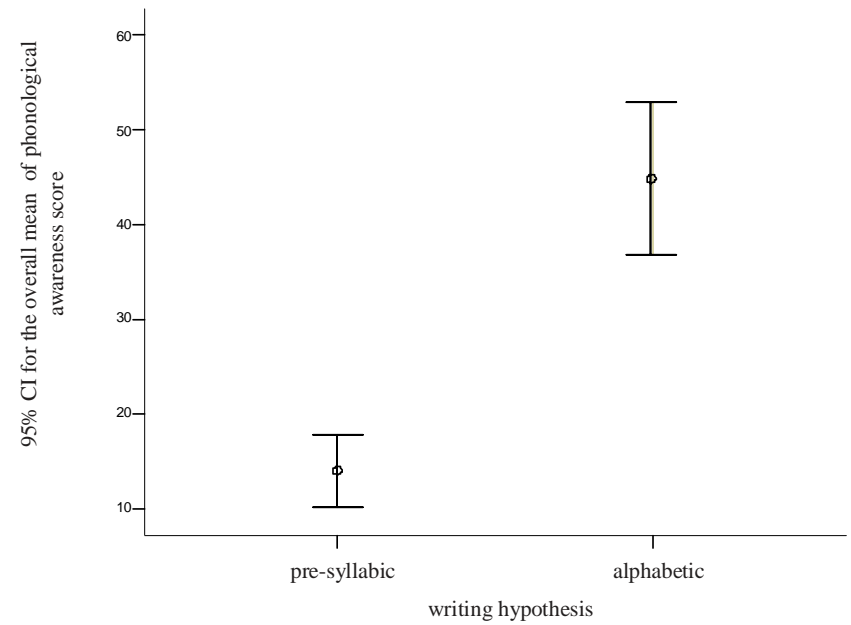

TABLE 2. Comparison between children with DS and TD regarding phonological awareness according to writing hypothesis ( $\mathrm{n}=10)$.

\begin{tabular}{|c|c|c|c|}
\hline \multirow{3}{*}{ Phonological Awareness } & \multicolumn{2}{|c|}{ Children } & \multirow{3}{*}{$\mathrm{p}^{*}$} \\
\hline & DS & $\mathrm{TD}^{* *}$ & \\
\hline & Mean \pm SD & Mean \pm SD & \\
\hline \multicolumn{4}{|l|}{ Pre-syllabic writing hypothesis } \\
\hline Syllable level - total & $11,1 \pm 3,19$ & $23,5 \pm 5,51$ & $<0,001$ \\
\hline Phoneme level - total & $3,00 \pm 1,41$ & $8,28 \pm 2,21$ & $<0,001$ \\
\hline Total score & $14,2 \pm 3,60$ & $31,8 \pm 6,52$ & $<0,001$ \\
\hline \multicolumn{4}{|l|}{ Alphabetic writing hypothesis } \\
\hline Syllable level - total & $30,3 \pm 2,99$ & $35,8 \pm 4,41$ & 0,034 \\
\hline Phoneme level - total & $14,8 \pm 2,36$ & $20,6 \pm 5,32$ & 0,016 \\
\hline Totalscore & $45,0+5,03$ & $56,4+8,96$ & 0,020 \\
\hline
\end{tabular}

\section{Discussion}

The results of the current study challenge the findings of Cossu et al.3, and are consistent with other studies that observed metalinguistic abilities in individuals with Down syndrome 4-19. It is believed that the measurements used by previous studies that did not report levels of phonological awareness in individuals with the syndrome were insensitive. In those studies, phonological awareness may have been masked by other deficient cognitive skills.

Previous studies have demonstrated the existence of positive correlations between reading skills and phonological awareness in individuals with Down syndrome 4,6-9,12,15-16,19-24. A significant positive association between metalinguistic skills and writing in 
individuals with the syndrome was observed in the current study. As many authors have argued, the relationship between phonological awareness and literacy is likely reciprocal, with progress in one area serving as a support for the development of the other 25 , 26. Some authors believe that the reciprocal relationship between phonological awareness and literacy might also be true for children with Down syndrome 7,14-15, 18. Due to the small sample size of the current study and due to the fact these data have not been longitudinally analyzed, further studies should be conducted in order to confirm such reciprocal relationship in individuals with Down syndrome.

In the Down syndrome data presented, while some phonological awareness skills improved with the learning of written language, others skills arose as a result of literacy. The experience of learning to read and write seems to be responsible for the emergence of most of the phonemic awareness skills in individuals with Down syndrome 4-5, 9,13. It was found in the current study that some syllabic awareness skills (segmentation and synthesis) and a certain phonemic sensitivity - observed on the performance on the word production with provided sound task - may already be present in individuals that are not yet literate. It is believed that these skills can provide support for early learning of reading and writing in children with Down syndrome.

The findings of the current study can be compared to studies that found significant differences on the performance of phonological awareness tasks when comparing groups of children with Down syndrome and groups with typical development matched for reading level 3,8,12-15, 19. In this study, children with Down syndrome performed significantly poorer than children with typical development - although both groups presented the same level of writing. Some authors suggest that these differences can be explained by the lower performance of individuals with the syndrome in tasks that require manipulation of phonological constituents14, such as exclusion and transposition.

\section{References}

1. Moojen S, Lamprecht RR, Santos RM, Freitas GM, Brodacz R, Siqueira M, Costa AC, Guarda E. CONFIAS Consciência fonológica: instrumento de avaliação sequencial. São Paulo: Casa do Psicólogo; 2003.

2. Cossu G, Rossini F, Marshall JC. When reading is acquired but phonemic awareness is not: a study of literacy in Down's syndrome. Cognition. 1993;46(2):129-38.

3. Cossu G, Marshall JC. Are cognitive skills a prerequisite for learning to read and write? Cognitive Neuropsychology. 1990;7(1):21-40.
Other researchers have found that these differences may persist even when global mental age is considered12. These findings suggest that difficulties in phonological awareness tasks might not be directly dependent on the reduced global cognitive level of children with the syndrome. However, other authors found that the difference may not be found on some tasks when subjects are matched by verbal mental age as measured by receptive vocabulary 8,19.

Another characteristic that can influence the performance of children with Down syndrome on phonological awareness tasks is the phonological working memory. There is significant evidence pointing to a specific deficit in working memory in individuals with Down syndrome 27-29.

Findings of this study are in agreement with previous studies in which positive correlations between measures of working memory and phonological awareness were found in individuals with Down syndrome 6,9,17,23. Children with more developed phonological working memory skills seem to have a better prognosis both for the development of phonological awareness and for learning the written language 5 .

\section{Conclusion}

The Brazilian children with Down syndrome evaluated in this study presented measurable levels of phonological awareness through the application of CONFIAS. The association between writing hypothesis and phonological awareness scores was positive and significant. We conclude that syllabic awareness skills might improve together with literacy in children with Down syndrome. However, phonemic awareness seems to emerge as a result of written language learning. It was also observed that these children might present poorer results when compared to children with typical development, despite similarities in writing hypothesis. The more developed the phonological working memory of children with Down syndrome is, the better will be their performance on tasks of phonological awareness.
4. Cupples L, Iacono T. Phonological awareness and oral reading skills in children with Down syndrome. J Speech Lang Hear Res. 2000;43(3):595-608.

5. Kay-Raining Bird E, Cleave PL, McConnell L. Reading and phonological awareness in children with Down syndrome. Am J Speech Lang Pathol. 2000;9(4):319-30.

6. Fletcher H, Buckley S. Phonological awareness in children with Down syndrome. Downs Syndr Res Pract. 2002;8(1):11-8.

7. Gombert JE. Children with Down syndrome use phonological knowledge in reading. Reading and Writing. 2002;15:455-69. 
8. Snowling MJ, Hulme C, Mercer RC. A deficit in rime awareness in children with Down syndrome. Reading and Writing. 2002;15:471-95.

9. Boudreau D. Literacy skills in children and adolescents with Down syndrome. Reading and Writing. 2002;15:497-525.

10. Kennedy EJ, Flynn MC. Training phonological awareness skills in children with Down syndrome. Res Dev Disabil. 2003a;24(1):44-57.

11. Laws G, Gunn D. Relationships between reading, phonological skills and language development in individuals with Down syndrome: A five year follow-up study. Reading and Writing: An Interdisciplinary Journal. 2002;15:527-48.

12. Verucci l, Menghini D, Vicari S. Reading skills and phonological awareness acquisition in Down syndrome. J Intellect Disabil Res. 2006;50(7):477-91.

13. Cardoso-Martins C, Michalick MF, Pollo TC. Is sensitivity to rhyme a developmental precursor to sensitivity to phoneme? Evidence from individuals with Down syndrome. Reading and Writing. 2002;15:439-54.

14. Cardoso-Martins C, Frith U. Can individuals with Down syndrome acquire alphabetic literacy skills in the absence of phoneme awareness? Reading and Writing. 2001;14:361-75.

15. Cardoso-Martins C, Frith U. Consciência fonológica e habilidades de leitura na Síndrome de Down. Psicologia: Reflexão e Crítica. 1999;12(1):209-24.

16. Cupples L, Iacono T. The efficacy of 'whole word' versus 'analytic' reading instruction for children with Down syndrome. Reading and Writing. 2002;15:549-74.

17. Kennedy E J, Flynn MC. Early phonological awareness and reading skills in children with Down syndrome. Downs Syndr Res Pract. 2003b;8(3):100-9.

18. Lara ATM, Trindade SHR, Nemr K. Desempenho de indivíduos com síndrome de Down nos testes de consciência fonológica aplicados com e sem apoio visual de figuras. Rev CEFAC. 2007;9(2):164-73.
19. Roch M, Jarrold C. A comparison between word and nonword reading in Down syndrome:the role of phonological awareness. J Commun Disord. 2008;41(4):305-18.

20. Ferreiro E, Teberosky A. Psicogênese da língua escrita. Porto Alegre: Artes Médicas; 1999.

21. Jerger J. Clinical experience with impedance audiometry. Archives of Otolaringol 1970;92(4):311-24.

22. Broadley I, MacDonald J. Teaching short term memory skills to children with Down's syndrome. Downs Syndr Res Pract. 1993;1(2):52-6.

23. Broadley I, MacDonald J, Buckley S. Working memory in children with Down's syndrome. Downs Syndr Res Pract. 1995;3(1):3-8.

24. Fowler AE, Doherty JB, Boynton L. The basis of reading skill in young adults with Down Syndrome. In: Nabel L, Rosenthal D. Down syndrome: living and learning in the communit. New York: John Wiley \& Sons; 1995. p. 182-96.

25. Morais J, Mousty P, Kolinsky R. Why and how phoneme awareness helps learning to read. In: Hulme C, Joshi RM. Reading and spelling: development and disorders. New Jersey: Lawrence Erlbaum; 1998. p. 127-51.

26. Freitas GCM. Consciência fonológica e aquisição da escrita: um estudo longitudinal [Tese]. Porto Alegre RS: PUCRS; 2004. 27. Jarrold C, Baddeley AD, Phillips CE. Verbal short-term memory in Down syndrome: a problem of memory, audition, or speech? J Speech Lang Hear Res. 2002;45(3):531-44.

28. Seung HK, Chapman R. Digit span in individuals with Down syndrome and in typically developing children: temporal aspects. J Speech Lang Hear Res. 2000;43(3):609-20.

29. Baddeley AD, Jarrold C. Working memory and Down syndrome. J Speech Lang Hear Res. 2007;51(12):925-31.

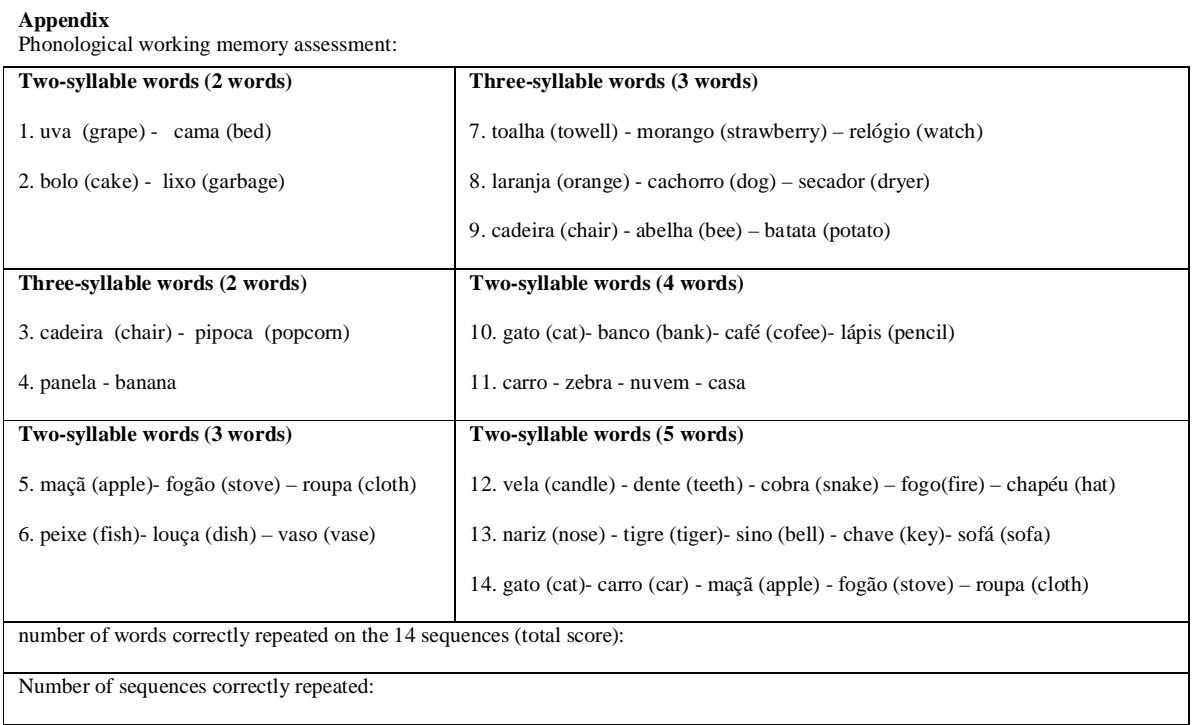

